The Myth of

American

Exceptionalism 
This page intentionally left blank 


\section{The Myth of}

American

Exceptionalism

GODFREY HODGSON

Yale University Press $\asymp$ New Haven and London 
Published with assistance from the Louis Stern Memorial Fund.

Copyright () 2009 by Godfrey Hodgson. All rights reserved. This book may not be reproduced, in whole or in part, including illustrations, in any form (beyond that copying permitted by Sections 107 and 108 of the U.S. Copyright Law and except by reviewers for the public press), without written permission from the publishers.

Designed by Nancy Ovedovitz and set in Minion type by The Composing Room of Michigan, Inc., Grand Rapids, Michigan. Printed in the United States of America by Sheridan Books, Ann Arbor, Michigan.

Library of Congress Cataloging-in-Publication Data Hodgson, Godfrey.

The myth of American exceptionalism / Godfrey Hodgson.

p. $\mathrm{cm}$.

ISBN 978-0-300-12570-2 (cloth : alk. paper) 1. National characteristics, American. 2. United States-Civilization.

3. United States-Foreign relations. 4. Nationalism-United States. 5. United States-Politics and government- 1989-.

6. United States-Foreign relations-1989-. I. Title. E169.1.H68 2008 973-dc22 2008026791

A catalogue record for this book is available from the British Library.

This paper meets the requirements of ANSI/NISO

Z39.48-1992 (Permanence of Paper). It contains 30 percent postconsumer waste (PCW) and is certified by the Forest Stewardship Council (FSC).

$\begin{array}{llllllllll}10 & 9 & 8 & 7 & 6 & 5 & 4 & 3 & 2 & 1\end{array}$ 
To all my friends in America 
There can be no deep disappointment where there is not deep love. Martin Luther King, Jr. 